\title{
Relation Between Resistance to Insecticides and Chemical Composition of Fat in the Cotton Leafworm Larvae (Spodoptera littoralis Boisd.)
}

The finding that there was no significant difference in the total fat contents between resistant and susceptible strains $^{1}$ suggested that there may be a qualitative difference between the fat of $R$-strains and that of the S-strain. This possibility was investigated.

Sixth instar larvae of DDT, methyl-parathion and carbaryl resistant strains and a susceptible strain of the cotton leafworm Spodopteva littoralis (Boisd.) were used. The rearing and development of resistance are recorded by $Z_{\text {AzOU }}$ et al. ${ }^{2}$.

About $5 \mathrm{~g}$ samples of larvae were dried and extracted with petroleum ether. I Aliquots of the petroleum ether extracts, representing $50 \mathrm{mg}$ of the total fat contents were directly methylated, after the solvent was removed, by refluxing with dry methanol and $\mathrm{HCl}$ gas for $2 \mathrm{~h}^{3}$. The reaction mixture was then diluted with water and extracted with petroleum ether. The petroleum ether extract of the methylated fatty acids was concentrated to a suitable volume. $1 \mu l$ from the final solution was analyzed for fatty acids methyl esters using a Pye Argon chromatograph with $\beta$-ionization detector and $4^{\prime} \times 1 / 8^{\prime \prime}$ column packed with $10 \%$ polyethylene-glycol adipate on 100-200 mesh celite. Conditions were as follows: Carrier gas-argon, flow rate $30 \mathrm{ml} / \mathrm{min}$, temperature of the column $172{ }^{\circ} \mathrm{C}$, and the detector voltage $1000 \mathrm{~V}$. The percentage of each fatty acid was calculated by comparing their peak area to those of standard solutions of acids methylated and extracted in a similar manner.

Gas liquid chromatographic analysis of the fatty acids present in the total fat content of cotton leafworm larvae showed, as indicated in the Figure, 5 detectable peaks. These peaks were found to correspond, according to their retention time: Palmetic $\left(\mathrm{C}_{16}: 0\right)$, stearic $\left(\mathrm{C}_{18}: 0\right)$, oleic $\left(\mathrm{C}_{18}: 1\right)$, linoleic $\left(\mathrm{C}_{18}: 2\right)$, and linolenic $\left(\mathrm{C}_{18}: 3\right)$. In the susceptible and the carbaryl resistant larvae, the concentration of palmetic acid was greater than that of linolenic acid. However in DDT, and methyl parathionresistant strains, the opposite was found, i.e. linolenic acid was greater in concentration than palmetic acid. Although stearic acid was present in appreciable quantities, it djd not show any correlation with resistance and susceptibility to insecticides. Oleic acid and linoleic acid were also present in detectable amounts but together with stearic, neither of them showed any relation to the resistance and susceptability to different insecticides.

The presence of linolenic acid in greater concentration than palmetic acid in the fat of the DDT-, and methylparathion resistant strains, may explain the ability of these strains to store both insecticides in their fat. PradHan et al. ${ }^{4}$ were able to show that organic insecticides dissolve better in insect cuticular waxes of low melting point than in saturated waxes of high melting point. By analogy, one would expect higher solubility of organic insecticides in fat rich in unsaturated fatty acids than in fat rich in saturated fatty acids.

Similar results were obtained with larvae of Heliothis virescens which are characterized by a greater natural tolerance than larvae of Heliothis zea and contain higher concentrations of the unsaturated linoleic and linolenic acids $^{5}$. This could affect the solubility of insecticides in lipids or the characteristics of the cell membrane.

Linolenic acid is considered to be one of the essential fatty acids for $S$. littoralis larvae ${ }^{6}$, i.e., it must be supplied in the diet. The biochemical pathway of this acid is probably different in DDT-resistant and methyl parathion resistant strains whose fat contained a greater percentage of linolenic acid than palmetic acid. This may be due to the inhibition of the enzymes that act on this acid after it is supplied by the diet and consequently accumulates in these strains.

Zusammenfassung. Im Körperfett eines insektizidsensitiven und eines carbaryl-resistenten Stammes von Spodopteva littoralis wird wenig Insektizid gespeichert und die Konzentration der Palmitinsäure ist höher als jene der Linolensëure. Für DOT- und methylparathionresistente Stämme gilt das Gegenteil. Es scheint, dass eine hohe Linolsäurekonzentration Voraussetzung für eine starke Einlagerung von Insektiziden in das Fett ist.

M. H. Balba ${ }^{7}$, M. D. Abdallah, H. Zazou and M. KANDIL

Department of Plant Protection, Faculty of Agriculture, Cairo University, Giza (Egypt), 25 September 1972.
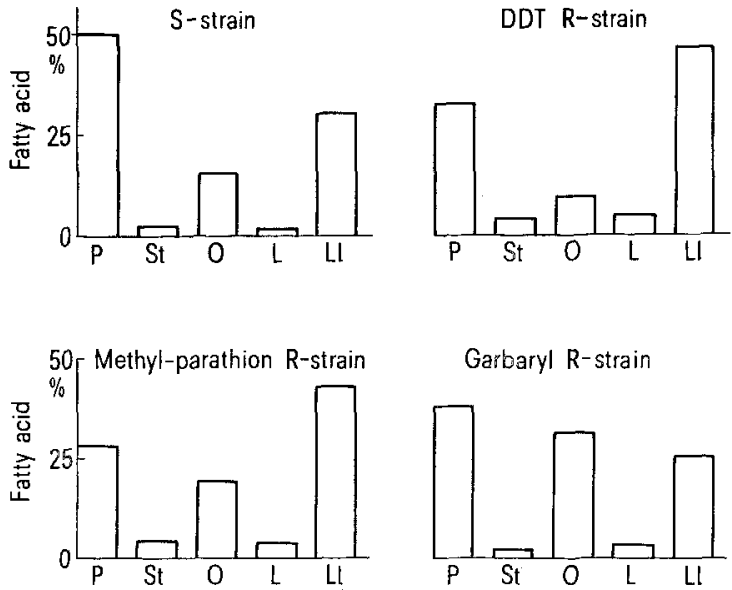

Garbaryl R-strain

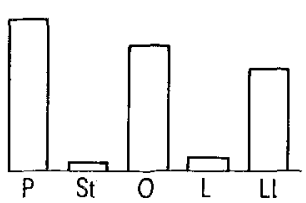

Percent of fatty acids in the fat of the 6 th instar larvae of $\mathrm{S}$ - and $\mathrm{R}$-strains of $S$. littoralis. $\mathrm{P}$, palmetic; St, stearic; O, oleic; L1 linolenic; L, linoleic.
I M.D. ABdallah, M.H. Zazou, M. Kandil and M.H. Balba, Experientia 29, 318 (1973).

a M.H. Zazou, M.D. Abdallah, M.H. Balba, M. Kandil, H. ElSAID and A. RAHAL, in preparation.

a C. H.U. Florence, H. Edward and J. Ahrens, Analyt. Chem. 31,307 (1959).

4 S. Pradhan, M. R.G. K. Nair and S. Krishnaswam, Nature 170, 169 (1952).

5 R.F. Mooke JR. and H.M. TAFT, J. econ. Entom. 64, 1060 (1971).

B H.Z. Levinson and A. Navon, J. Insect Physiol. 15, 591 (1969).

7 Present address: Canada Department of Agriculture Research Branch, Research Station, University Campus, Saskatoon, Saskatchewan, Canada. 